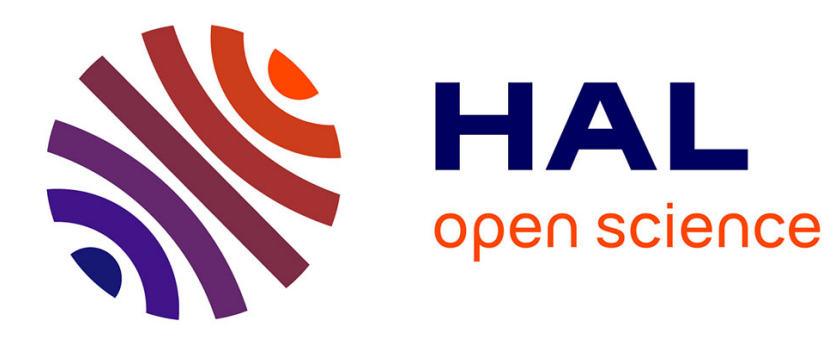

\title{
On the origins of a Conflict of Interest in the Mutual Fund Industry
}

\author{
Sébastien M. Lemeunier
}

\section{To cite this version:}

Sébastien M. Lemeunier. On the origins of a Conflict of Interest in the Mutual Fund Industry. 2011, pp.21. hal-00592108

\section{HAL Id: hal-00592108 \\ https://essec.hal.science/hal-00592108}

Submitted on 11 May 2011

HAL is a multi-disciplinary open access archive for the deposit and dissemination of scientific research documents, whether they are published or not. The documents may come from teaching and research institutions in France or abroad, or from public or private research centers.
L'archive ouverte pluridisciplinaire HAL, est destinée au dépôt et à la diffusion de documents scientifiques de niveau recherche, publiés ou non, émanant des établissements d'enseignement et de recherche français ou étrangers, des laboratoires publics ou privés. 


\title{
On the Origins of a Conflict of Interest in the Mutual Fund Industry
}

\author{
Research Center \\ ESSEC Working Paper 1102 \\ February 2011
}

Sébastien M. Lemeunier 


\section{On the origins of a Conflict of Interest in the Mutual Fund}

\section{Industry}

Sébastien M. Lemeunier ${ }^{1}$

\footnotetext{
${ }^{1}$ Professor, Department of finance European Business School Paris and Adjunct Professor, Department of Economics, ESSEC Business School Paris

Email : slemeunier@gmail.com,

Telephone : 0033620232210
} 


\title{
On the origins of Conflict of Interest in the Mutual Fund Industry.
}

\begin{abstract}
This article discusses conflicts of interest existing between investors and their financial advisors. Several contributions in this field treated this question in relation either with invested amount or with expected holding period of the mutual fund. Our paper considers an approach globalizing these two parameters. The first part describes the organization of mutual fund fees in the US. Thanks to a numerical simulation, the second part emphasizes the conflict of interest focusing on the expected holding period. The third one analyses the changes of variables and their consequences on characteristics of investors concerned by this conflict of interest.
\end{abstract}

JEL classification : G23; G24; G28

Keywords : Mutual funds; Broker Dealer; Regulation; conflict of interest

Cet article traite des conflits d'intérêts existant entre les investisseurs et leur conseiller financier. Des contributions antérieures ont apporté des éclairages sur cette question en considérant soit les montants investis soit l'horizon d'investissement des investisseurs. Cet article intègre ces différentes dimensions dans une approche globale. La première partie décrit le système des frais aux Etats-Unis. La seconde, grâce à une simulation numérique, met en évidence le conflit d'intérêt en se concentrant uniquement sur l'horizon d'investissement. La troisième partie traite des changements de variables et leurs conséquences sur les caractéristiques des investisseurs concernés par ce conflit d'intérêts.

Classification JEL : G23; G24; G28

Mots clés : OPCVM ; Conseiller financier ; Réglementation ; Conflit d'intérêt. 


\section{Introduction}

The mutual fund industry in the United States has known a tremendous growth over the last 30 years. By 2009, half of American households held shares in one or several mutual funds (ICI 2010). Moreover 8,000 mutual funds manage 11,121 billion dollars in the United-States (ICI (2010)). This success has been supported by substantial marketing efforts and generous commission schemes to induce sales brokers.

To purchase mutual fund shares indeed, investors can turn to many types of intermediaries and have choices as how to pay for their services. They may pay a "sales load" at the time they purchase shares, or a deferred sales load when they redeem shares, and/or they may have to pay annually $12 \mathrm{~b}-1$ fees that are deducted from the fund's assets. Combined together, these fees entailed the creation of different share classes typically labeled class A, B and C shares. Investors make a choice between these share classes according to their characteristics in terms of invested amounts and expected holding period. However it may occur that the related compensation scheme of their financial advisor doesn't match their particular needs. In doing so, the existence of this conflict of interest drove to numerous litigation cases (Senator et al (2006) and Krawczyk (2004).

So what are the characteristics of investors exposing them to this conflict of interest?

Are investors more or less exposed as determining parameters them to this conflict of interest vary?

Most of studies explain this conflict of interest either with the Expect Holding period O'Neal (1999b), Livingston and O'Neal (1998), Davis (1995) or with the invested amounts Foster (2009), Senator et al 2006, SEC 2004. The latter has been the most frequently treated especially because it entailed many litigation cases. Our approach integrates these two causes to explain this conflict of interest.

To answer these questions, a preliminary part introduces an overview of mutual fund fees in the US.

Thanks to numerical simulations in a second part, it is determined characteristics of investors concerned by a conflicting situation with their financial advisor. It is made the restrictive assumption that invested amounts are lower than $\$ 50,000$. However, this assumption will be relaxed in the last part. In a third part, varying variables of the model, it is emphasized the evolution of these characteristics.

\section{Mutual fund fees}


Investors willing to buy mutual fund shares do not all call for brokers' services and it implies a different pricing structure. It is common practice to distinguish load from no-load mutual funds.

Load funds use brokerage firms to distribute their shares or any other intermediary between them and investors. These intermediaries advise investors in order to guide their choices and to provide additional services ${ }^{2}$. Investors care about these guidance and services and it justifies the payment of load fees.

A no-load fund is a mutual fund whose shares are sold without a sales commission and with limited distribution fees ${ }^{3}$. No-load funds adopt a more direct relationship with their clients in order to promote their shares. It relies on relatively cheaper distribution methods (advertisement, direct mails...).

In doing so, non-sophisticated investors tend to invest in mutual funds with load fees, under the influence of marketing and their brokers' recommendations ICI (1997), Del Guercio (2002) whereas sophisticated investors choose no-load mutual funds. Thereafter this paper focuses on nonsophisticated investors as it is considered conflicts of interests between investors and their brokers.

According to their invested amount and their expected holding period, investors have to make a choice among different classes of shares which result from combinations of three types of fees. Three main share classes are usually mentioned and typically denoted by A, B, C as described in table 1 (Annex $1)$ :

- Class A shares charge front-end loads declining according to the level of the invested amount and 12b-1 fees relatively lower in comparison to the other share classes. Class A shares are the only one to propose front-end loads. In addition to their profitable aspect, front-end loads induce investors to stay longer in the fund in order to amortize them. Compared to the Class B and C shares described hereafter, funds with Class A shares are more suitable for investors with a relatively longer expected holding period.

- Class B shares are an alternative to Class A shares for investors with a long-term investment horizon. They adopt a coercive approach to prevent from an early withdrawal of the investor. Instead of paying front-end loads, the investor pays deferred loads in case of redemption of shares. These deferred loads decrease with each year the share is held. Deferred loads decline to zero over 7 years. Additionally 12b-1 fees for Class B and C shares are of the same order and then relatively higher to those applied to Class A shares. Class B shares are usually converted into Class A shares after the eighth year of investment to avoid that investors bear higher 12b-1 fees too long.

- Class C shares charge relatively higher $12 b-1$ fees. They also include deferred loads of $1 \%$ if the investor redeems his or her shares within the first year and zero the subsequent years. Mutual

\footnotetext{
${ }^{2}$ This advice includes the fund selection, the asset allocation of the investor's portfolio and taxation. Services usually include the opening of an account, financial orientated press, an availability to answer to investors' questions, an overview of the account by web...

${ }^{3}$ Distribution fees, also called Rule $12 \mathrm{~b}-1$ fee can not exceed 0.25 percent per year. (ICI 2009 Mutual fund fact book)
} 
funds using Class C Shares are also called "level load funds". Considering the relative combinations of fees they use, Class $\mathrm{C}$ shares are particularly suitable for investors with a short term expected holding period. Moreover, they allow a more reactive management of the investor's portfolio changing more frequently of mutual fund at a lower cost.

\section{The conflict of interest analysis}

The conflict of interest results from the inadequacy between interests of the investor in terms of fees charged and the related compensation of the broker. In such a situation a broker may be induced to advise a class of share not suitable to an investor according to his or her characteristics in terms of expected holding period or invested amount. In doing so, what are the characteristics of investors concerned by conflicting situations with their financial advisor?

In this part, it is only considered situations where invested amounts are lower than $\$ 50,000$ to avoid any questions concerning discount policy and to isolate characteristics related to the expected holding period of the investor. Characteristics concerning the invested amount will be treated further.

\subsection{The model}

To demonstrate the conflict of interest, we compare ${ }^{4}$ the annual Holding-Period Return (HPR) of investors with the Present Value Commission (PVC) of brokers for each share class. A numerical simulation is implemented and results are graphically represented. A first step consists in presenting formulas related to the annual Holding-Period Return and the Present Value Commission. Next simulations are applied according to different expected holding-period and then preferences of investors and brokers are compared.

\section{The annual holding-period return of investors (HPR)}

The Holding Period Return is the total net return of a mutual share over the period during which it was held. To compare this HPR between different investment horizons and between share classes we annualize the HPR to obtain a percentage per year.

For each class of share, the related net expected annualized holding-period return is compared in order to estimate the most suitable share class according to the expected holding period of the investor. Each class A, B, C share has a specific combination of fees as described in Table 1 according to the corresponding formulas hereafter:

\footnotetext{
${ }^{4}$ This approach comparing share classes has been used by Collins (2004), O'Neal (1999a and 1999b), Livingston and O’Neal (1998) and Davis (1995).
} 
$H P R_{A, t}=\left\{\left(1-F L_{A}\right)\left[\left(1+R_{\text {daily }}\right) \times\left(1-E_{\text {daily }, A}\right)\right]^{250 t}\right\}^{1 / t}-1$

$\mathrm{FL}_{\mathrm{i}}$ denotes the front-end loads charged by the fund $\mathrm{i}, \mathrm{R}_{\text {daily }}$ stands for its daily expected returns and $\mathrm{E}_{\text {daily }}$ is the daily expense ratio ${ }^{5} \mathrm{t}$ is the holding period, in years.

$$
\begin{aligned}
& \operatorname{HPR}_{\mathrm{B}, \mathrm{t}}=\left\{\left[\left(1+\mathrm{R}_{\text {daily }}\right) \times\left(1-\mathrm{E}_{\text {daily,B }}\right)\right]^{250 \mathrm{t}}-\mathrm{DL}_{\mathrm{B}, \mathrm{t}}\right\}^{1 / \mathrm{t}}-1, \quad \mathrm{t} \leq z \\
& \mathrm{HPR}_{\mathrm{B}, \mathrm{t}}=\left\{\left[\left(1+\mathrm{R}_{\text {daily }}\right) \times\left(1-\mathrm{E}_{\text {daily,B }}\right)\right]^{250 \mathrm{z}} \times\left[\left(1+\mathrm{R}_{\text {daily }}\right) \times\left(1-\mathrm{E}_{\text {daily,A }}\right)\right]^{250(\mathrm{t}-\mathrm{z})}\right\}^{1 / \mathrm{t}}-1, \quad \mathrm{t}>z
\end{aligned}
$$

For the Class B share, the formula takes into account the deferred loads (DL) for the corresponding year and the conversion into Class A share after $\mathrm{z}=8$ years.

$H P R_{C, t}=\left\{\left[\left(1+R_{\text {daily }}\right) \times\left(1-E_{\text {daily }, C}\right)\right]^{250 t}-D L_{C, t}\right\}^{1 / t}-1$

The annual net Holding Period Return is graphically represented using figures appearing in Table 2. An average gross return of $12 \%$ per year has been assumed for this numerical simulation. The chart below displays the evolution of the annual Holding Period Return according to the expected holding period of investors for each share class.

\section{Chart 1 : Annual net average holding Period Return (HPR)}

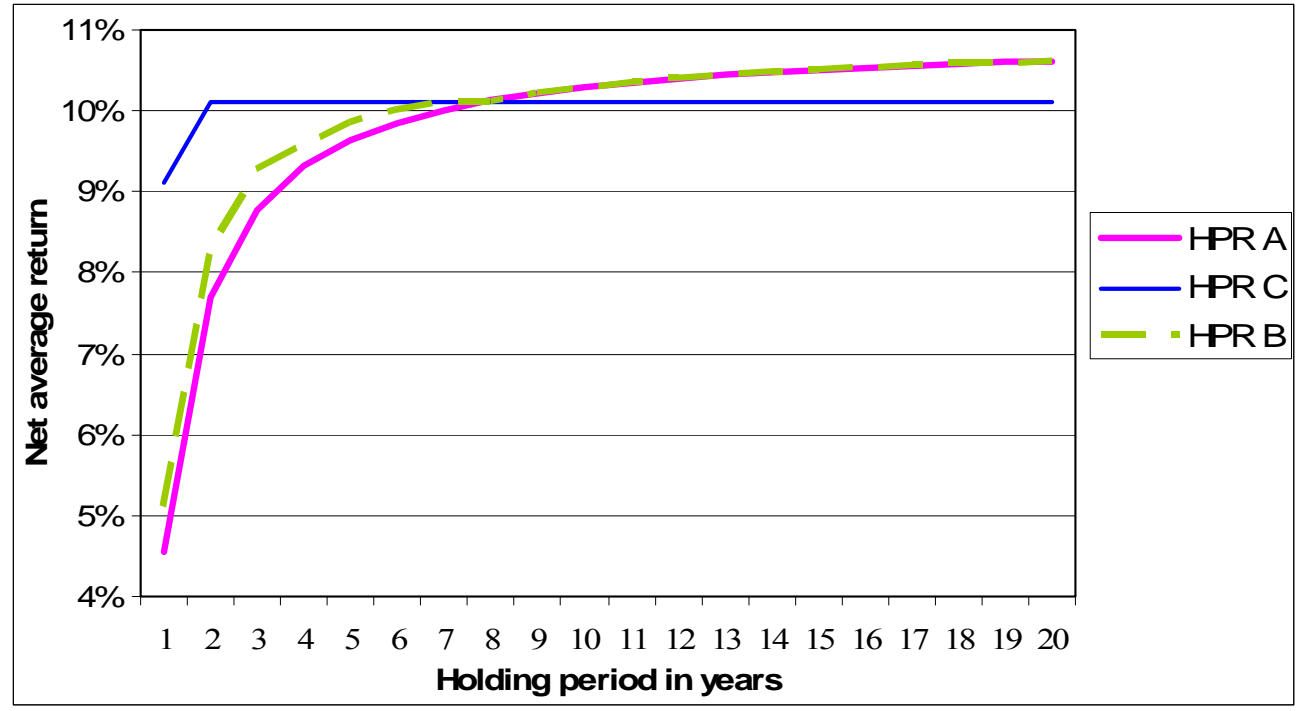

Each point on one of these curves corresponds to a date at which an investor withdraws his or her money from a mutual fund. The corresponding coordinate on the $\mathrm{Y}$ axis is the average net return an investor could benefit each year until the date of withdrawal. Assuming an average gross return of $12 \%$, an investor that held a fund with a Class A share for 4 years can expect to obtain each year an average net return of $9.2 \%$.

\footnotetext{
${ }^{5}$ The daily expense ratio results from the annual expense ratio comprising 12b-1 fees and management fees charged to the investor every year and as long as he or she holds his or her shares of mutual fund.
} 
Because $\mathrm{HPR}_{\mathrm{A}}$ and $\mathrm{HPR}_{\mathrm{B}}$ are very similar, the comparison will mainly focus on $\mathrm{HPR}_{\mathrm{A}}$ and $\mathrm{HPR}_{\mathrm{C}}$ for the relevance of the analysis. The intersection point of $\mathrm{HPR}_{\mathrm{A}}$ and $\mathrm{HPR}_{\mathrm{C}}$ means that for the corresponding holding period, an investor is indifferent between having a Class A share and a Class $\mathrm{C}$ share. $t{ }^{*}{ }_{\text {inv }}$ denotes this intersection point.

Chart 1 shows that an investor with an investment horizon longer than $t^{*}{ }_{\text {inv }}=7.9$ years would prefer to acquire a Class A share. Conversely, an investor with a shorter investment horizon would prefer to have a Class $\mathrm{C}$ share.

$t^{*}{ }_{\text {inv }}$, the intersection point of $\mathrm{HPR}_{\mathrm{A}}$ and $\mathrm{HPR}_{\mathrm{C}}$, is solution of the system:

$$
\begin{aligned}
& H P R_{A, t_{i n v}^{*}}=H P R_{C, t_{i n v}^{*}} \\
& \left\{\left(1-F L_{A}\right)\left[\left(1+R_{\text {daily }, A}\right) \times\left(1-E_{\text {daily }, A}\right)\right]^{250 t_{\text {tivv }}^{*}}\right\}^{1 / t_{\text {tinv }}^{*}}-1=\left\{\left[\left(1+R_{\text {daily }, C}\right) \times\left(1-E_{\text {daily }, C}\right)\right]^{250 t_{i n v}^{*}}-D L_{C, t}\right\}^{1 / t_{i n}^{*}}-1 \\
& \left.t_{i n v}^{*}=\frac{-D L_{C, t}-\ln \left(1-F L_{A}\right)}{250 \ln \left(\frac{\left(1+R_{\text {daily }, A}\right) \times\left(1-E_{\text {daily }, A}\right)}{\left(1+R_{\text {daily }, C}\right) \times\left(1-E_{\text {daily }, C}\right.}\right)}\right)
\end{aligned}
$$

\section{The Present Value Commission of brokers (PVC)}

Financial advisors are rewarded for getting a new client through two types of commissions:

- An initial sales commission $\left(\mathrm{IC}_{\mathrm{i}}\right)$ stemming from front-end loads and paid when the new client enters into the fund and

- A trailing sales commission $\left(\mathrm{TC}_{\mathrm{i}}\right)$ that is paid quarterly to the financial advisor as long as his or her client keeps his or her shares.

As described in Table 1 the financial advisor's earnings depend of the share class sold to the investor.

The Present Value Commission represent the total compensation that the broker receives for the entire duration the investor keeps his or her shares.

The trailing commission for the fund $\mathrm{i}\left(\mathrm{TC}_{\mathrm{i}}\right)$ is paid to the broker on each quarter and deducted from $12 \mathrm{~b}-1$ fees. $\mathrm{TC}_{\mathrm{i}}$ is computed on a daily basis $\mathrm{n}$. Assuming that a quarter includes 63 working days, the following expression gives the trailing commission for the class i share on the quarter $\mathrm{m}$ :

$$
\text { TCquarterly }_{i, m}=\sum_{m=1}^{63} T C_{i, \text { daily }}\left[\left(1+R_{\text {daily }}\right)\left(1-E_{i, \text { daily }}\right)\right]^{63(m-1))+n}
$$

Then, the expression of the Present Value Commission can be written as the sum of the Initial Commission and the discounted Trailing Commissions. $\mathrm{T}$ is the whole length of time in quarters the investor holds his or her shares and $\mathrm{k}$ is the discount rate.

Apart from front-end loads applied to the Class A share, the formula used to obtain the Present Value Commission is the same for the three classes of share $i$. 
$P V C_{i, T}=I C_{i}+\left(1-F L_{i}\right) \sum_{m=1}^{T} \frac{\text { TCquarterly }_{i, m}}{(1+k)^{m}}$

To solve this geometric sequence (5), our developments are the following:

$P V C_{i, T}=I C_{i}+\left(1-F L_{i}\right) \sum_{m=1}^{T} \frac{\alpha_{i} \frac{\beta_{i}}{\beta_{i}-1} \frac{\beta_{i}^{63 m}}{\beta_{i}^{63}}\left(\beta_{i}^{63}-1\right)}{(1+k)^{m}}$

which equals

$$
P V C_{i, T}=I C_{i}+\gamma_{i} \sum_{m=1}^{T}\left(\frac{\beta_{i}^{63}}{1+k}\right)^{m}
$$

with $\beta_{i}=\left\lfloor\left(1+R_{\text {daily }}\right)\left(1-E_{i, \text { daily }}\right)\right], \quad \alpha_{\mathrm{i}}=$ TCquarterly $_{\mathrm{i}} \quad$ and $\quad \gamma_{i}=\left(1-F L_{i}\right) \frac{\alpha_{i}}{\beta_{i}^{63}}\left(\frac{\beta_{i}^{64}-\beta_{i}}{\beta_{i}-1}\right)$

The present Value Commission of brokers is graphically represented according to the expected holding-period of investors for each share class ${ }^{6}$ as below. According to these equations and using figures in Table 1, we conduct a numerical simulation as shown in Table 2. Calculations are based on a gross annual return of $12 \%$ and a risk free rate of $3 \%$ has been applied to discount commissions of brokers.

Chart 2 : Present Value Commission (PVC) of brokers with a risk free rate

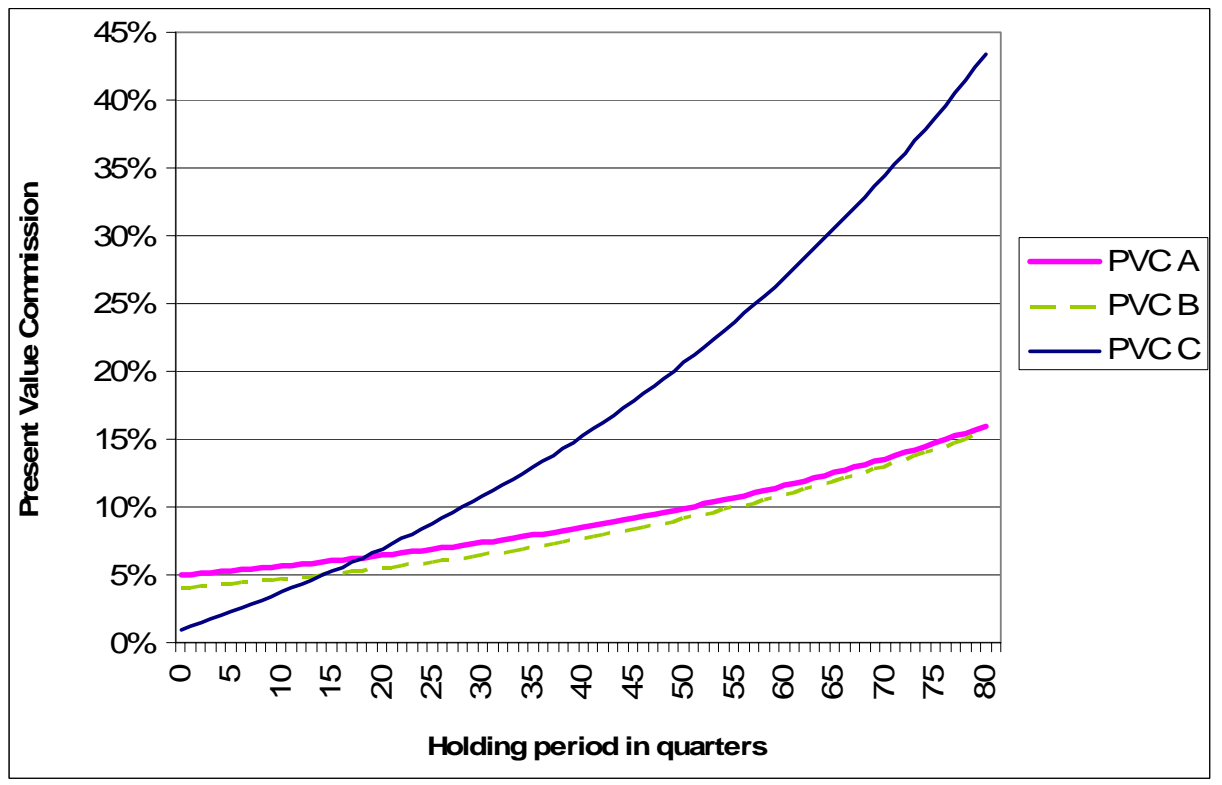

${ }^{6}$ Class A and B shares are also very similar from brokers' point of view. It is then focused on the comparison between $\mathrm{A}$ and $\mathrm{C}$ share classes. 
In this Chart, an intersection point is also noticeable between the Present Value Commissions related to classes $\mathrm{A}$ and $\mathrm{C}$ shares. This point is denoted by $\mathrm{t}^{*}$ Brok representing the holding period for which brokers are indifferent between advising a class A share and a Class $\mathrm{C}$ share. $\mathrm{t}^{*}{ }_{\text {Brok }}$ appears after 4.4 years corresponding to a PVC of $6,21 \%$.

$\mathrm{t}^{*}{ }_{\text {Brok }}$ is solution of the system ${ }^{7}$ :

$$
\begin{gathered}
P V C_{A, t_{\text {Brok }}^{*}}=P V C_{C, t_{\text {Brok }}^{*}} \\
I C_{A}+\gamma_{A} \sum_{m=1}^{t_{\text {Brok }}^{*}}\left(\frac{\beta_{A}{ }^{63}}{1+k}\right)^{m}=I C_{C}+\gamma_{C} \sum_{m=1}^{t_{\text {Brok }}^{*}}\left(\frac{\beta_{C}{ }^{63}}{1+k}\right)^{m}
\end{gathered}
$$

\section{Divergent / convergent interest areas and characteristics of investors}

Comparing the broker's PVC with the investor's HPR according to various investment horizons, the conflict of interest arises indeed.

- A broker could prefer to advise a Class C share to a long term investor, while a Class A share would be more suitable.

- A broker could prefer to advise a Class A share to a short term investor, while a Class C share would be more suitable.

To be more precise a comparison of indifference points of investors and brokers reveals a potential conflict of interest but not for every expected holding period. It may be delimited areas of holding period with a conflict of interest and areas of holding period where interests of brokers and investors converge.

Points of indifference $t^{*}$ inv and $t^{*}{ }_{\text {Brok }}$ between classes $A$ and $C$ shares are respectively set after 7.9 years corresponding to a HPR of $10.11 \%$ and after 4.4 years corresponding to a PVC of $6.21 \%$.

Based on these key figures, these areas of divergent and convergent interests are shown in the Table 3.

\begin{tabular}{|c|c|c|c|}
\hline & $\begin{array}{c}\text { Area with a conflict } \\
\text { of interest }\end{array}$ & $\begin{array}{c}\text { Area with } \\
\text { convergent interests }\end{array}$ & $\begin{array}{c}\text { Area with a conflict of } \\
\text { interest }\end{array}$ \\
\hline $\begin{array}{c}\text { Points of } \\
\text { indifference }\end{array}$ & $0 \quad \mathrm{t}^{*}{ }_{\text {Brok }}=$ & 4.4 years $\quad t^{*}$ & 7.9 years \\
\hline $\begin{array}{c}\text { Brokers prefer to } \\
\text { advise }\end{array}$ & A & $\mathrm{C}$ & $\mathrm{C}$ \\
\hline $\begin{array}{c}\text { Is preferable for } \\
\text { Investors }\end{array}$ & $\mathrm{C}$ & $\mathrm{C}$ & $\mathrm{A}$ \\
\hline
\end{tabular}

Table 3 : Conflict of interest between brokers and advisors

\footnotetext{
${ }^{7}$ The existing conditions for the intersection point $t^{*}$ brok are $\mathrm{IC}_{\mathrm{A}}>\mathrm{IC}_{\mathrm{C}}$ and $\gamma_{\mathrm{C}}>\gamma_{\mathrm{A}}$.
} 
For the period of time bounded by the segment $\left[t^{*}{ }_{\text {inv }} ; t^{*}{ }_{\text {Brok }}\right]$ interests of brokers ans nvestors converge. This area with convergent interests is spread over a period of $\mathrm{t}^{*}{ }_{\text {inv }}-\mathrm{t}^{*}{ }_{\text {Brok }}=3.5$ years.

In doing so, investors characterized by an expected holding period included in $\left[\mathrm{t}^{*}{ }_{\mathrm{inv}} ; \mathrm{t}^{*}{ }_{\text {Brok }}\right]$ are not concerned by this conflict of interest. Out of this area, investors are all concerned.

As can be seen $t^{*}{ }_{\text {inv }}$ and $t *{ }_{\text {Brok }}$ may vary with variables of the model. Therefore the convergent interest area is unstable and its dynamics should be analyzed.

\section{Dynamics of the convergent interest area}

Assuming that investors are uniformly distributed according to their expected holding period, variations of the convergent interest area may give information about the proportion of investors concerned by the conflict of interests. This study may help whether to suggest solutions to enlarge the convergent interest area or to stress situations in which more or less investors are exposed to conflicts of interests.

Convergent and divergent interest areas vary according to exogenous factors as the discount rate, expectations about the market trend, the specific return of a fund, the level of fees and commissions. It is then analyzed effects of these variations on the convergent interest area. The assumption of an invested amount lower than $\$ 50,000$ will be relaxed at the end of this part.

To keep consistency with the philosophy of share classes, the analysis of the conflict of interest respects the following assumptions:

- Let $\mathrm{E}_{\mathrm{A}}, \mathrm{E}_{\mathrm{C}}, \mathrm{FL}_{\mathrm{A}}, \mathrm{IC}_{\mathrm{A}}, \mathrm{IC}_{\mathrm{C}}, \mathrm{TC}_{\mathrm{A}}, \mathrm{TC}_{\mathrm{C}}, \mathrm{R}_{\mathrm{A}}, \mathrm{R}_{\mathrm{C}} \geq 0$ and $\mathrm{FL}_{\mathrm{c}}=0$

- Let $\mathrm{E}_{\mathrm{A}} \leq \mathrm{E}_{\mathrm{C}}, \mathrm{IC}_{\mathrm{A}} \geq \mathrm{IC}_{\mathrm{C}}$ and $\mathrm{TC}_{\mathrm{A}} \leq \mathrm{TC}_{\mathrm{C}}$.

- If $t^{*}{ }_{\text {inv }}>\mathrm{t}^{*}$ brok or if $\mathrm{t}^{*}$ brok $>\mathrm{t}_{\text {inv }}^{*}$, the convergent interest area is respectively comprised between $\left[\mathrm{t}_{\text {brok }}^{*} ; \mathrm{t}^{*}{ }_{\text {inv }}\right]$ or between $\left[\mathrm{t}^{*}{ }_{\text {inv }} ; \mathrm{t}^{*}{ }_{\text {brok }}\right]$. If $\mathrm{t}_{\text {inv }}{ }=\mathrm{t}_{\text {brok }}{ }$, the convergent interest area disappears. To be consistent with the current conflict of interest, it is only studied the case where $t_{\text {inv }}^{*} \geq t^{*}$ brok. From this perspective, $t^{*}$ inv is the right side of the segment $\left[\mathrm{t}_{\text {brok }}^{*} ; \mathrm{t}_{\text {inv }}\right]$ and its maximal value tends to infinite. $\mathrm{t}^{*}$ brok is the left side of $\left[\mathrm{t}^{*}{ }_{\text {brok }} ; \mathrm{t}^{*}\right.$ inv $]$ and its minimal value is assumed to be zero.

- $\quad$ effect of a discount rate variation

Proposition 1: a positive change of the preference for the present or the risk apprehension of brokers $k$ decreases the convergent interest area.

Proof 1: Because $t_{i n v}^{*}$ does not depend of $k$, it is always the same: $\frac{\partial t_{i n v}^{*}}{\partial k}=0$. Since TCquaterly $\mathrm{y}_{\mathrm{C}, \mathrm{m}}$ is assumed to be higher than $\mathrm{TCquaterly}_{\mathrm{A}, \mathrm{m}}$, if $k$ increases, equation (8) shows that slopes of $P V C_{A}$ and 
$P V C_{C}$ diminish but in a lower proportion for $P V C_{A}$. Then $t_{B r o k}^{*}$ increases and $\frac{\partial t_{b r o k}^{*}}{\partial k}>0$. For any increase of $k, \Delta\left(t^{*}{ }_{\text {inv }}-t^{*}{ }_{\text {brok }}\right)<0$.

Then, one can infer that brokers' risk apprehension represented by an increase of $k$ enlarges the conflict of interest areas at the expense of the convergent interest area. It entails that more unstable is the investment horizon of the client or more uncertain is the advisor's professional situation and more the convergent interest area shrinks.

Additionally, the conflict of interest disappears between brokers with a professional time horizon shorter than $\mathrm{t}^{*}$ brok and investors with a long term horizon, because he or she will prefer to recommend Class A shares.

\section{- effect of market trend expectations}

Proposition 2 : If market trend forecasts are optimistic, they imply a higher expected gross return and the convergent interest area increases.

Proof 2 : for an identical variation of $R_{\text {daily,A }}$ and $R_{\text {daily,C}}$ the expression $\ln \left(\frac{\left(1+R_{d a i l y, A}\right) \times\left(1-E_{d a i l y, A}\right)}{\left(1+R_{d a i l y, C}\right) \times\left(1-E_{d a i l, C}\right)}\right)$ stay the same and $t^{*}{ }_{i n v}$ does not change: $\frac{\partial^{2} t_{i n v}^{*}}{\partial R_{A} \partial R_{C}}=0$. Since $T C_{\text {quarterly,C }}$ is higher than $T C_{\text {quaterly,A }}$ and according to equation (7), an identical rise of $R_{\text {dailyA }}$ and $R_{\text {daily,C }}$ will imply a higher increase of the slope for $P V C_{C}$ than for $P V C_{A} \cdot{ }^{*}{ }_{B r o k}$ decreases such as $\frac{\partial^{2} t_{b r o k}^{*}}{\partial R_{A} \partial R_{C}}<0$ and $\Delta\left(t^{*}{ }_{i n v}-t^{*}{ }_{b r o k}\right)>0$.

So, optimistic market trend forecasts do not only imply an additional demand for mutual funds (Karceski (2002)) but they also imply an enlargement of the convergent interest area. The corollary is that pessimistic market trend forecasts decrease the convergent interest area. Nevertheless, this potential increase of the conflict of interest area is "compensated" by the decrease of the demand that characterizes an expected bear market period.

\section{- effect of a variation of fees and commissions}

\section{Effect of a $F L_{1}$ increase}

Proposition 3 : If $F L_{A}$ increases the convergent interest area increases.

Proof 3: equation (5) shows that any increase of $F L_{A}$ implies that $-\ln \left(1-F L_{A}\right)$ raises and then $t^{*}{ }_{i n v}$ increases. If $F L_{A}$ increases, $\gamma_{A}$ decreases and according to expression (8) the slope of $P V C_{A}$ 
diminishes. It entails a reduction of $t^{*}$ brok. Therefore $\frac{\partial t_{b r o k}^{*}}{\partial F L_{A}}<0$ and $\frac{\partial t_{i n v}^{*}}{\partial F L_{A}}>0$, hence for an increase of $F L_{A}, \Delta\left(t_{i n v}^{*}-t_{b r o k}^{*}\right)>0$

\section{Effect of a daily expense ratio increase $^{8}$}

Proposition 4: An increase of the daily expense ratio of the class A or an increase of the daily expense ratio of the Class $C$ share increase or reduces the convergent interest area, respectively.

Proof 4: $250 \ln \left(\frac{\left(1+R_{\text {daily }, A}\right) \times\left(1-E_{\text {daily }, A}\right)}{\left(1+R_{\text {daily }, C}\right) \times\left(1-E_{\text {daily }, C}\right)}\right)$ being lower than 1, if $E_{\text {dail }, A}$ or $E_{\text {dail }, C}$ increase, according to equation (5) $t^{*}{ }_{i n v}$ increases or decreases respectively: $\frac{\partial t_{i n v}^{*}}{\partial E_{d a i l y, A}}>0$ and $\frac{\partial t_{i n v}^{*}}{\partial E_{C}}<0$. According to (6), for a positive variation of $E_{d a i l y, A}$ or $E_{d a i l y, C}$, the slope of $P V C_{A}$ decreases or the slope of $P V C_{C}$ increases, respectively: $\frac{\partial t_{\text {brok }}^{*}}{\partial E_{\text {daily,A }}}<0$ and $\frac{\partial t_{\text {brok }}^{*}}{\partial E_{\text {daily,C }}}>0$. Therefore, it implies that $\frac{\partial\left(t_{i n v}^{*}-t_{b r o k}^{*}\right)}{\partial E_{A}}>0$ and $\frac{\partial\left(t_{i n v}^{*}-t_{b r o k}^{*}\right)}{\partial E_{C}}<0$.

An increase of the daily expense ratio $\mathrm{E}_{\mathrm{A}}$ and/or front-end loads $\mathrm{FL}_{\mathrm{A}}$ implies an increase of the convergent interest area. From the conflict of interest perspective, one can say that an increase of Class A share fees has a virtuous effect ${ }^{9}$, all other things being equal. On the contrary, an increase of fees related to Class $\mathrm{C}$ share entails a decrease of the convergent interest area.

\section{Effect of brokers' commission increase}

Any variation of commissions has no impact on the net average return of investors. Therefore, it is only considered their effect on $t^{*}$ brok.

Proposition 7: an increase of commissions from Class A shares or Class C shares decreases or increases the convergent interest area, respectively.

Proof 7 : according to equation(8), an increase of $I C_{A}$ or $I C_{C}$ leads to a parallel upward shift of $P V C_{A}$ or PVC $C_{C}$ and $t_{\text {brok }}^{*}$ increases or diminishes, respectively: $\frac{\partial t_{b r o k}^{*}}{\partial I C_{A}}>0$ and $\frac{\partial t_{b r o k}^{*}}{\partial I C_{C}}<0$. One can infer that $\frac{\partial\left(t_{i n v}^{*}-t_{b r o k}^{*}\right)}{\partial I C_{A}}<0$ and $\frac{\partial\left(t_{i n v}^{*}-t_{b r o k}^{*}\right)}{\partial I C_{C}}>0$.

\footnotetext{
${ }^{8}$ It is reminded that $\mathrm{E}_{\text {daily, }}$ is the daily expense ratio that includes "other expenses" and $12 \mathrm{~b}-1$ fees.

${ }^{9}$ It can also be demonstrated that $\mathrm{E}_{\mathrm{A}}$ has a larger impact than $\mathrm{FL}_{\mathrm{A}}$ on the convergent interest area.
} 
According to equation (7) an increase of $\mathrm{TC}_{\mathrm{A}}$ or an increase of $\mathrm{TC}_{\mathrm{C}}$ entails a steeper $\mathrm{PVC}_{\mathrm{A}}$ curve or a steeper $\mathrm{PVC}_{\mathrm{C}}$ curve, respectively. Therefore $\frac{\partial t_{b r o k}^{*}}{\partial T C_{A}}>0$ and $\frac{\partial t_{b r o k}^{*}}{\partial T C_{C}}<0$, hence $\frac{\partial\left(t_{i n v}^{*}-t_{b r o k}^{*}\right)}{\partial T C_{A}}<0$ and $\frac{\partial\left(t_{i n v}^{*}-t_{b r o k}^{*}\right)}{\partial T C_{C}}>0$

In doing so, considering proposition (6) and reminding that $12 \mathrm{~b}-1$ fees are included in the daily expense ratio $E_{i}$, if an increase of brokers' commissions is funded by an increase of fees in the same proportion, the effect on the convergent interest area is cancelled.

\section{- Evolution of the conflict of interest according to invested amounts}

The delimitation of these conflict of interest areas has been done assuming that invested amounts are lower than $\$ 50,000$. Nevertheless, depending on the importance of the amount invested, Class A shares offer discounted loads. It is then examined if investors with larger amounts will be more or less exposed to the conflict of interest. It is applied to front-end loads the sliding scale according to the invested amount and breakpoints as described in Table 1.

Additionally, while it is observed the evolution of the convergent interest area for class A and C shares, it is included the Class B share.

\section{Chart 3 : Evolution of points of indifference between class $A$ and $C$ shares according to invested}

\section{amounts}

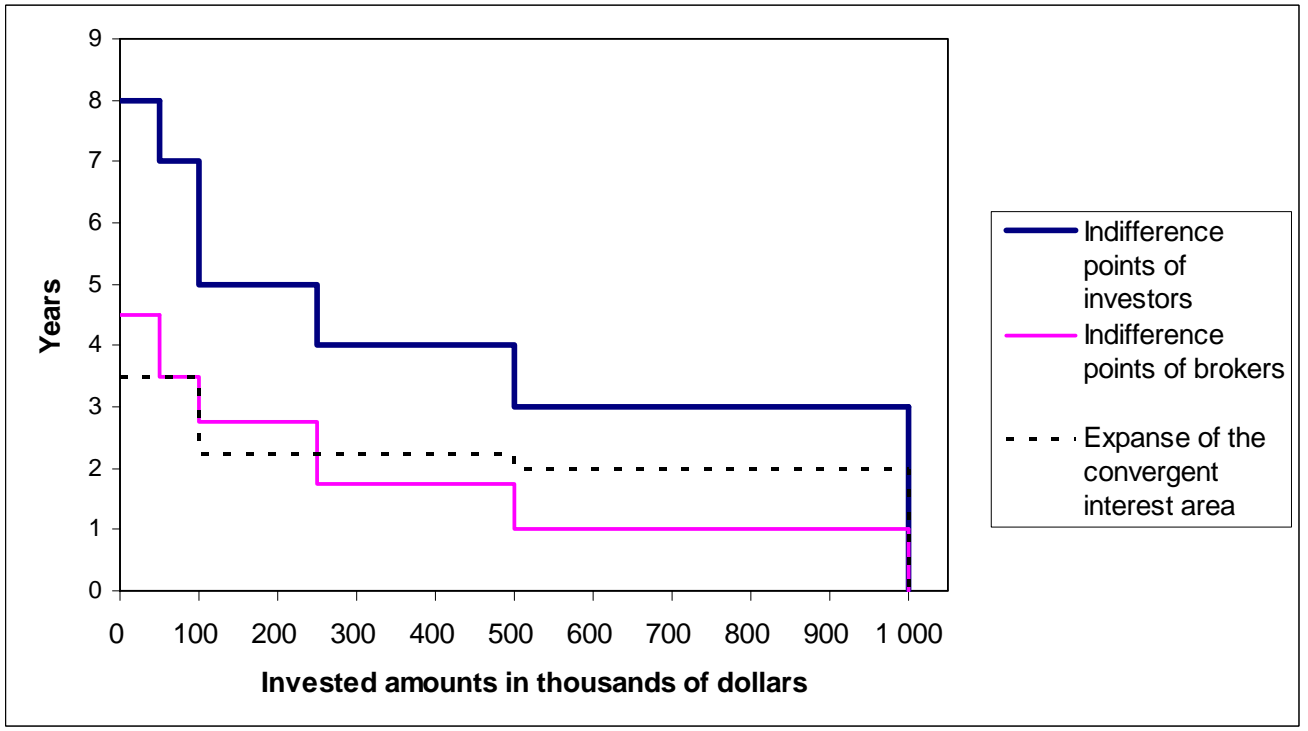

As a result of a numerical simulation, this chart shows the evolution of indifference points between class $\mathrm{A}$ and $\mathrm{C}$ shares and the conflict of interest according to invested amounts. The dotted line represents the expanse of the convergent interest area between brokers and investors. It steadily 
decreases to equal zero for amounts exceeding 1 million dollars. Surprisingly, investors with the largest amounts are also the most concerned by this conflict of interest. In other words, it is shown that the most important clients are and the most they are exposed to the conflict of interest with their financial advisor.

However, if the invested amount is higher than the breakpoint $\$ 100,000$ class A shares offer a discount to investors. For this level of invested amount, investors with a shorter expected holding period prefer to buy Class A Shares. On the other hand, brokers prefer advising a Class B Share to have higher commissions ${ }^{10}$. Hereafter, it is shown the evolution of points of indifference

\section{Chart 4 : Evolution of points of indifference between class A, B and C shares according to}

\section{invested amounts}

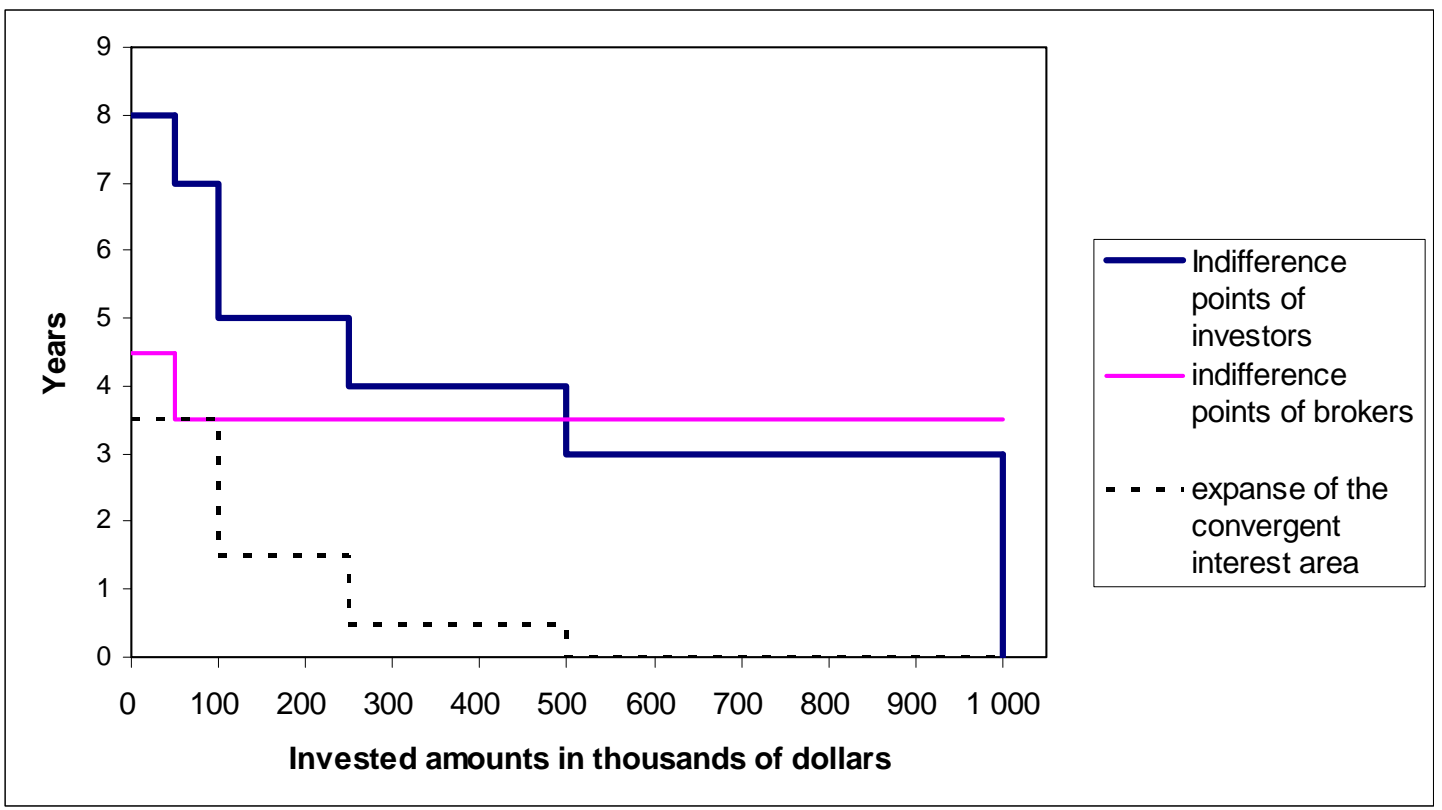

From $\$ 50,000$, brokers are indifferent between class $A$ and $B$ share and from $\$ 100,000$ they systematically are more rewarded when they sell a class B share rather than selling a class A share.

From this breakpoint, higher invested amount are and narrower is the convergent interest area. Additionally, including Class B Share, the convergent interest disappears for lower invested amount $\$ 500,000$ in our example).

This last diagram stresses that investors the most exposed to the conflict of interest exposure are those with the largest amounts. This conclusion takes into account a comparison between class A, B and C shares and explains the conflict of interest with the expected holding period and the invested amount.

\footnotetext{
${ }^{10}$ However the SEC have prohibited this type of practice mentioning it into an amendment of the Rule $12 \mathrm{~b}-1$ in 2004. Securities and Exchange Commission [2004] « Prohibition on the Use of Brokerage Commissions to Finance Distribution.”; SEC [release No. IC-26591; File No. S7-09-04] October 14, 2004
} 


\section{Conclusion}

It has been demonstrated the existence of a conflict of interest between investors and their financial advisor. To be concerned by these potentially conflicting situations, we have determined characteristics of investors in terms of expected holding period for their mutual fund shares and invested amount.

Isolating investors with an invested amount lower than $\$ 50,000$, it has been stressed with numerical simulations the existence of a convergent interest area and areas of conflict of interest according to their expected holding period. For these amounts lower than $\$ 50,000$ it has been focused on a comparison between Class A and C shares. Varying variables of the model, we show that characteristics of investors exposed to the conflict of interest change.

Any increase of market trend expectations or Front end loads or daily expense ratio of class A share implies an increase of the convergent interest area.

An increase of the discount rate of brokers or daily expense ratio of Class $\mathrm{C}$ share shrinks the convergent interest area.

Integrating invested amounts and comparisons with class B shares, it appears that the convergent interest area shrinks for amounts higher than $\$ 100,000$ and disappears for amounts higher than $\$ 500,000$. From this breakpoint, any kind of investor is exposed to a potential conflict of interest with his or her financial advisor.

\section{Bibliography}

- Alexander, G., Jones, D., Nigro P., 1998. Mutual fund shareholders: characteristics, investor knowledge, and sources of information. Financial Services Review 7, 301-316

- Capon N., Fitzsimons G., Prince R., 1996. An individual level analysis of the mutual fund investment decision. Journal of Financial Services Research 10, 59-82.

- Collins S., 2004. The effect of 12b-1 plans on mutual fund investors. Working paper, ICI.

- Davis L., 1995. A New Look at SEC Rule 12b-1. Securities Regulation Law Journal, Vol 23.

- Del Guercio D., Tkac P., 2002. The determinants of the flows of funds of managed portfolios: Mutual funds vs. pension funds. Journal of Financial and Quantitative Analysis Vol. $37 \mathrm{~N}^{\circ} 4$ pages 523-557.

- Foster P., 2009. Mutual Fund Multi-Class Offerings: Addressing Conflicts of Interest Through Meaningful Disclosure and Robust Sales Practice Protocols. The investment Lawyer Vol. 16, No. 6 
- Gerut A., 2008. Share Class Suits Raise Questions About Prospectus Accuracy. BoardIQ December 2, 2008.

- Investment Company Institute - ICI, 2002. Total Shareholder Cost of Mutual Funds: an update. Fundamentals. September Vol. 11, No. 4 September 2002

- Investment Company Institute - ICI, 1997. Understanding Shareholders' Use of Information and Advisers. Investment Company Institute Research Series. Spring 1997

- Investment Company Institute - ICI, 2009. Investment Company Fact Book $49^{\text {th }}$ Edition.

- Karceski J., 2002. Returns-Chasing behavior, Mutual funds and Beta's death. Journal of Financial and Quantitative Analysis vol 37.

- Krawczyk S.S., 2004, Compensation Practices for Retail Sales of Mutual Funds. The Journal of Investment Compliance, Spring 2004

- Leonard-Chambers V., Bogdan M., 2007. Why Do Mutual Fund Investors Use Professional Financial Advisers? ICI Research Fundamentals, Vol. 16, No. 1, April 2007.

- Livingston M., O'Neal E., 1998. The cost of mutual fund distribution fees. Journal of Financial Research vol XXI, N².

- Mahoney P., 2004. Manager-Investor Conflicts in mutual funds. Journal of Economic Perspectives, Vol. 18 Issue 2.

- Morey R., 2003. Should you carry the load? A comprehensive analysis of load and no-load mutual fund out-of-sample performance. Journal of Banking and Finance 27.

- O'Neal E., 1999a. Mutual fund share classes and broker incentives. Financial Analyst Journal 55 September/October 1999 76- 87.

- O'Neal E., 1999b. Mutual fund share classes and conflicts of interest between brokers and investors. Working paper, Wake Forest University.

- SECURITIES AND EXCHANGE COMMISSION - SEC, 2004. Prohibition on the use of Brokerage Commissions to Finance Distribution. SEC 17 CFR Part 270 release No. IC-26591; File No. S7-09-04 October 14, 2004

- SECURITIES AND EXCHANGE COMMISSION - SEC, 2008. SEC Improves Disclosure for Mutual Fund Investors. SEC. November 19, 2008.

- SECURITIES AND EXCHANGE COMMISSION - SEC, 2010 Mutual Fund Distribution Fees; Confirmations; Proposed Rule. August 4, 2010

- Senatore C.V., Malina S. M., Jones C.H., Galeano M., Walter E.B., 2006, Mutual Funds - The Broker Dealer Perspective Securities Industry Association Compliance \& Legal Division. March 21, 2006

- Sirri E., Tufano P., 1998. Costly search and mutual fund flows. The Journal of Finance Vol. 53, No. 5, 1589-1622.

- Sirri E., Tufano P., 1993. Competition and change in the mutual fund industry. Samuel Hayes 
III, ed. Financial Services Perspectives and Challenges (HBS Press, Boston, Mass).

- Walsh L., 2004. The costs and benefits to fund shareholders of $12 \mathrm{~b}-1$ plans: an examination of fund flows, expenses and returns. ; SEC; May 2004

- Wilcox R. T., [2003]; "Bargain hunting or star gazing? Investor's preferences for stock mutual funds"; Journal of Business Vol 76 n²; 2003

- Zhao Xinge [2003]; "The role of brokers and financial advisors behind investments into load funds"; Working paper; November 2003

\section{Annex 1}

Table 1

Typical Class structures for Load Mutual Funds

\begin{tabular}{|c|c|c|c|c|c|c|c|}
\hline \multirow[b]{2}{*}{$\begin{array}{l}\text { Share } \\
\text { class }\end{array}$} & \multicolumn{5}{|c|}{ Typical class structure for Load Mutual Fund } & \multicolumn{2}{|c|}{$\begin{array}{c}\text { Broker compensation } \\
\text { arrangement }\end{array}$} \\
\hline & $\begin{array}{c}\text { 12b-1 } \\
\text { fees }\end{array}$ & $\begin{array}{c}\text { Other } \\
\text { expenses }\end{array}$ & Deferred load & $\begin{array}{l}\text { Front-end } \\
\text { Initial investment }\end{array}$ & Load & $\begin{array}{c}\text { Initial } \\
\text { commission }\end{array}$ & $\begin{array}{c}\text { Trailing } \\
\text { commission }\end{array}$ \\
\hline A & $0.25 \%$ & $0.70 \%$ & $0 \%$ & $\begin{array}{l}<\$ 50,000 \\
\$ 50,000-\$ 100,000 \\
\$ 100,000-\$ 250,000 \\
\$ 250,000-\$ 500,000 \\
\quad \$ 500000-\$ 1,000,000 \\
\quad>1000000 \$\end{array}$ & \begin{tabular}{|c|}
$5.75 \%$ \\
$4.50 \%$ \\
$3.50 \%$ \\
$2.50 \%$ \\
$2 \%$ \\
$0 \%$ \\
\end{tabular} & $\begin{array}{c}5 \% \\
4 \% \\
3.20 \% \\
2.25 \% \\
1.70 \% \\
1 \% \\
\end{array}$ & $0.25 \%$ \\
\hline B & $1 \%$ & $0,70 \%$ & $\begin{array}{c}5 \% \text { the } 1 \mathrm{st} \\
\text { year } \\
4 \% \text { the } 2^{\text {nd }} \text { year } \\
3 \% \text { the } 3 \text { rd year } \\
3 \% \text { the } 4 \text { th year } \\
2 \% \text { the } 5 \text { th year } \\
1 \% \text { the } 6 \text { th year }\end{array}$ & $\begin{array}{c}0 \% \\
\text { Conversion into } \mathrm{Cl} \\
\text { share after the 8th } \\
\text { investment. }\end{array}$ & $\begin{array}{l}\text { ass } A \\
\text { ear of }\end{array}$ & $4 \%$ & $0.25 \%$ \\
\hline $\mathbf{C}$ & $1 \%$ & $0.70 \%$ & $\begin{array}{c}1 \% \text { the first } \\
\text { year } \\
0 \% \text { after the first } \\
\text { year }\end{array}$ & $0 \%$ & & $1 \%$ & $1 \%$ \\
\hline
\end{tabular}

Cf: O'Neal E. S. [1999];"Mutual fund share classes and conflict of interest between brokers and investors"; Working paper; 1999

O'Neal provides his article with data obtained from an average sample composed of 20 equity mutual funds among the largest.

12b-1 fees are an annual marketing or distribution fee on a mutual fund. They are paid every year as long as the investor holds his or her shares.

Deferred loads : also known as a back-end sales charge, they are imposed when an investor redeems shares. The percentage charged declines the longer shares are held. 
Other expenses: annual fees non related to distribution expenses.

Front-end loads are sales charge applied at the time of the initial purchase for a mutual fund. It is deducted from the investment amount.

\section{Annex 2}

Table 2

Numerical simulations of investor Annual Holding-Period Returns and Broker Present Value Commissions

\begin{tabular}{|c|c|c|c|c|c|c|}
\hline \multirow{2}{*}{$\begin{array}{c}\text { Investment Duration in } \\
\text { years }\end{array}$} & \multicolumn{3}{|c|}{ Annual Holding-Period Return } & \multicolumn{3}{|c|}{ Present Value Commission } \\
\hline & HPR $_{\mathrm{A}, \mathrm{t}}$ & HPR $_{\mathrm{B}, \mathrm{t}}$ & $\mathbf{H P R}_{\mathrm{C}, \mathrm{t}}$ & $\mathbf{P V C}_{\mathrm{A}, \mathrm{t}}$ & $\mathbf{P V C}_{\mathrm{B}, \mathrm{t}}$ & $\mathbf{P V C}_{\mathrm{C}, \mathrm{t}}$ \\
\hline 0 & $0 \%$ & $0 \%$ & $0 \%$ & $5,00 \%$ & $4,00 \%$ & $1,00 \%$ \\
\hline 1 & $4.56 \%$ & $5.11 \%$ & $9.11 \%$ & $5,25 \%$ & $4,26 \%$ & $2,03 \%$ \\
\hline 2 & $7.70 \%$ & $8.28 \%$ & $10.11 \%$ & $5,51 \%$ & $4,54 \%$ & $3,14 \%$ \\
\hline 3 & $8.77 \%$ & $9.28 \%$ & $10.11 \%$ & $5,80 \%$ & $4,83 \%$ & $4,32 \%$ \\
\hline 4 & $9.31 \%$ & $9.55 \%$ & $10.11 \%$ & $6,10 \%$ & $5,15 \%$ & $5,59 \%$ \\
\hline 5 & $9.63 \%$ & $9.84 \%$ & $10.11 \%$ & $6,43 \%$ & $5,49 \%$ & $6,95 \%$ \\
\hline 6 & $9.85 \%$ & $10.01 \%$ & $10.11 \%$ & $6,79 \%$ & $5,86 \%$ & $8,39 \%$ \\
\hline 7 & $10.01 \%$ & $10.11 \%$ & $10.11 \%$ & $7,18 \%$ & $6,24 \%$ & $9,95 \%$ \\
\hline 8 & $10.12 \%$ & $10.11 \%$ & $10.11 \%$ & $7,59 \%$ & $6,69 \%$ & $11,60 \%$ \\
\hline 9 & $10.21 \%$ & $10.20 \%$ & $10.11 \%$ & $8,04 \%$ & $7,16 \%$ & $13,38 \%$ \\
\hline 10 & $10.29 \%$ & $10.28 \%$ & $10.11 \%$ & $8,52 \%$ & $7,67 \%$ & $15,28 \%$ \\
\hline 11 & $10.35 \%$ & $10.34 \%$ & $10.11 \%$ & $9,04 \%$ & $8,22 \%$ & $17,31 \%$ \\
\hline 12 & $10.39 \%$ & $10.39 \%$ & $10.11 \%$ & $9,60 \%$ & $8,82 \%$ & $19,48 \%$ \\
\hline 13 & $10.44 \%$ & $10.43 \%$ & $10.11 \%$ & $10,21 \%$ & $9,46 \%$ & $21,81 \%$ \\
\hline 14 & $10.47 \%$ & $10.47 \%$ & $10.11 \%$ & $10,86 \%$ & $10,15 \%$ & $24,30 \%$ \\
\hline 15 & $10.50 \%$ & $10.50 \%$ & $10.11 \%$ & $11,56 \%$ & $10,90 \%$ & $26,96 \%$ \\
\hline 16 & $10.53 \%$ & $10.53 \%$ & $10.11 \%$ & $12,32 \%$ & $11,70 \%$ & $29,81 \%$ \\
\hline 17 & $10.56 \%$ & $10.55 \%$ & $10.11 \%$ & $13,14 \%$ & $12,57 \%$ & $32,85 \%$ \\
\hline 18 & $10.58 \%$ & $10.57 \%$ & $10.11 \%$ & $14,02 \%$ & $13,50 \%$ & $36,11 \%$ \\
\hline 19 & $10.60 \%$ & $10.59 \%$ & $10.11 \%$ & $14,96 \%$ & $14,51 \%$ & $39,60 \%$ \\
\hline 20 & $10.61 \%$ & $10.61 \%$ & $10.11 \%$ & $15,99 \%$ & $15,59 \%$ & $43,33 \%$ \\
\hline
\end{tabular}


ESSEC Business School Avenue Bernard Hirsch BP 50105

95021 Cergy-Pontoise Cedex France

Tél. + $33(0) 134433000$

Fax $+33(0) 134433001$

www.essec.fr

ESSEC Executive Education

CNIT BP 230

92053 Paris-La Défense

France

Tél. +33(0)146924900

Fax +33(0)1 46924990

http:l/formation.essec.fr

ESSEC Business School

Singapore Campus

100 Victoria Street

National Library Building \# 13-02

Singapore 188064

essecasia@essec.fr

Tél. +65 68849780

Fax +6568849781

www.essec.edu

\section{Informations}

Hanane Rahmoune +33 (0)134433358

rahmoune@essec.edu

www.essec.fr

research.center@essec.fr

ISSN 1291-9616 